\title{
Seduced or Sceptical Consumers? Organised Action and the Case of Fair Trade Coffee
}

\author{
by Janette Webb \\ University of Edinburgh \\ Sociological Research Online, Volume 12, Issue 3, \\ $<$ http://umw. socresonline.org.uk/12/3/5.html> \\ doi:10.5153/sro. 1536
}

Received: 1 Sep 2006 Accepted: 16 Apr 2007 Published: 30 May 2007

\begin{abstract}
This article brings together research on political consumerism, social movements and markets to analyse the phenomenon of fair trade coffee. It does this to demonstrate the influence of organised consumers in shaping markets, and to show that people are not inevitably individualised and seduced by the power of corporate marketing. The case of fair trade coffee is used because of the pivotal role of coffee in the global economy. 'Organised consumers' are treated as comprised of three inter-connecting, fluid, components: an activist core, responsible for building the campaign and its alternative trade networks; a widely dispersed alliance of civil society and social movement organisations, articulating the connections between trade justice, human rights and wellbeing; and an 'outer edge' of quasi-organised consumers acting as part of a largely imagined group by using economic capital to express cultural and political values. Despite saturated markets, and oligopoly among suppliers in a highly rationalised supply chain, such consumer movements have been instrumental in an emerging new trade paradigm, which has influenced the business and product strategies of trans-national corporations. The creation, and rising sales, of Fair Trade products are evidence of the role of consumers as sceptical actors, challenging consumerism and the ethics of a supply chain which impoverishes coffee farmers. Although the future trajectories of fair trade campaigns and products are uncertain, their growth indicates that people continue to draw on sources of social identity beyond that of 'consumer'.
\end{abstract}

\section{Keywords: Consumption, Consumers, Fair Trade, Coffee, Social Movement Organisations}

\section{Introduction}

1.1 Growing recognition of the cultural and material significance of consumerism in affluent societies is only recently being matched by growth in sociological analyses of consumption. Warde (2005) argues that contemporary sociology of consumption is however skewed towards general theories of consumer culture on the one hand and case studies of symbolic meanings of consumption in the formation of identity on the other. The result is an overly-individualised model, which fails to engage with evidence of the diversity of consumption practices, or their social organisation. Neglect of evidence about the particular and differentiated qualities of practice contributes to a normative construct of a consumer overwhelmed by the seductive power of marketing and advertising. In his theory of consumer culture, Bauman $(2000 ; 2004)$ for example argues that accelerating consumerism contributes to a state of 'liquid modernity' which leaves people struggling to resist the seductions of endless unnecessary, products. The resulting market-mediated life is portrayed as self-sealing and inescapable: 'a comprehensive world view, a comprehensive attitude to the world and universal precepts of life strategy' (Bauman, 2004: 305). In their account of emotional isolation in a globalising economy, Elliott and Lemert (2006) also argue that market principles are ruthlessly colonising every sphere of life: 'our language for representing and elaborating our image of self-identity is more and more fixed into a syntax of possession, ownership, control and market value' (p. 41). Such theories are in themselves seductive, but their conclusions are not derived from an interrogation of consumption practices. There is a consequent risk that, instead of providing the means to a critical deconstruction of consumerism, sociology becomes complicit in furthering its normative status and in construing people as the self-interested, but essentially passive, recipients of its products. Such methodological individualism (Warde, 2005) leaves little space for investigating the organised, and quasiorganised, activities of people in framing, politicising and contesting consumerism and its assumptions of a self-absorbed individualism. 
2.1 Evidence from the sociology of social movements, and from political science, nevertheless suggests that there is conspicuous growth of political activism concerned with contesting consumerist values and the exploitative supply chain relationships associated with neo-liberal economics. Studies of political participation for example report the growth of different forms of political consumerism since the 1990s, including increased use of consumer boycotts of targeted mainstream products on the one hand, and active buying (also called "buycotts") of alternatives on the other (Bostrum et al, 2004; Micheletti, 2003; Norris, 2002; Stolle et al 2005). Such positive political consumerism entails buying specific products because of their attributed ethical qualities, symbolised in eco-labels, fair trade labels, organic food labels, and stewardship certification (Micheletti, 2004). Studies of social movements also point to the prominent role of self-organising trans-national networks, which frame and develop political meanings for consumer activism through public protest and awareness-raising campaigns (Della Porta and Diani, 2006; Della Porta et al, 2006).

2.2 The emergence, and increasing sales, of 'Fair Trade'-labelled products, such as coffee, may therefore serve as indicators of the influence of organised consumer movements and a developing politicisation of consumption. In this paper I use the example of Fair Trade coffee to provide evidence of the market impact of collective consumer agency. In order to do this I draw on a conceptual framework derived from economic sociology, which treats markets, not as governed by fixed economic laws, but as constituted through the reflexive and indeterminate interactions of their multiple constituencies (Callon, 1998; Callon et al, 2002; Smelser and Swedberg, 2005). Although such analyses have concentrated on the role of experts, nonexpert organised consumers can also be regarded as intermediaries exercising a form of collectively distributed agency (Mallard, 2006) among a multiplicity of actors who play a constitutive role in product markets.

\section{The Rise of Fair Trade Coffee}

3.1 The phenomenon of Fair Trade coffee is an apt illustration of the performative influence of organised consumers over product markets for two reasons. First coffee is central to global political economy and is therefore a critical indicator of changes in consumer markets. Coffee is the second most valuable commodity after oil, with an estimated annual retail value of $\$ 55$ billion (ICO, 2006), and it is a crucial source of foreign exchange for Latin American, African and Asian countries (Bates, 1998;Paige, 1998). The coffee product market is characterised by oligopoly among the main importers and processors: the four main coffee roasters, Kraft, Nestle, Procter and Gamble and Sara Lee, together with the German firm Tchibo, buy approximately half of the global supply of green beans. Despite static consumer demand, with consumption averaging 4.6 kilos per person per year (see Table 1), its processed end products constitute a highly profitable market in the affluent societies of North America, Europe and Australasia.

\begin{tabular}{l} 
Table 1 Per Capita Consumption of Coffee (in Kgs) in Selected Importing \\
Countries, 2001-04 \\
\hline
\end{tabular}

Source: Coffee Market Report, 2006, International Coffee Organization, London, http://www.ico.org/

3.2 Second, despite the dominance of trans-national firms and a static market, sales of Fair Trade-labelled 
coffee are experiencing significant growth. Globally Fair Trade is small business, comprising $1-3 \%$ of sales of all instant, roast and ground coffee products, but the rate of growth is averaging $8 \%$ per annum (Lewin et al, 2004). The financial value of such products is also increasing rapidly, making a small share of the market very valuable. Between 2003 and 2004, the value of Transfair ${ }^{[1]}$-Certified coffee sales in the USA and Canada increased by $77 \%$ and $51 \%$ respectively to a total of $\$ 382.4$ million (Table 2 ).

\begin{tabular}{|l|l|l|l|}
\hline \multicolumn{4}{|c|}{ Table 2. Retail Value of Coffee Certified by Transfair, North America 2003-04. } \\
\hline & 2003 & 2004 & $\%$ change \\
\hline USA & $\$ 208$ million & $\$ 369$ million & $77 \%$ \\
\hline Canada & $\$ 15.46$ million & $\$ 23.4$ million & $51 \%$ \\
\hline
\end{tabular}

(Fair Trade Trends, 2005 www.fairtradefederation.com)

3.3 In Europe, the Fair Trade market share of higher value roast and ground coffee has increased markedly, if unevenly, over the last five years (Table 3). Notably in the UK, Fair Trade products now comprise $20 \%$ of the retail value of ground coffee, with sales increasing from $£ 13.7 \mathrm{~m}$ in 1998 to $£ 65.8 \mathrm{~m}$ in 2005 (http://www.fairtrade.org.uk/about_sales.htm, 28/02/2007). In contrast, in Germany there has been little change. Such patterns raise questions about the differential growth of sales, which are beyond the scope of this paper. The high rate of growth in the UK is however suggestive of the coincidence of retail growth in availability of a wide range of coffee drinks through cafe chains, with anti-poverty activism, through movements such as Jubilee 2000, on the one hand (Della Porta et al, 2006), and the establishment of the Fair Trade company, Café Direct, as a prominent alternative supplier, on the other.

\begin{tabular}{|c|c|c|}
\hline & 1999 & 2004 \\
\hline United Kingdom & 1.5 & 20.0 \\
\hline Switzerland & 3.0 & 6.0 \\
\hline Denmark & 1.8 & 2.0 \\
\hline Ireland & 0.5 & 2.0 \\
\hline Germany & 1.0 & 1.0 \\
\hline
\end{tabular}

(Extracted from Lewin et al, 2004)

\section{Explaining the Rise of Fair Trade Coffee 1: Trans-national Corporations Manipulate Consumers?}

4.1 Before examining the arguments that the growth of Fair Trade coffee constitutes evidence of the market impact of organised consumer movements, it is important to assess the counter-argument that Fair Trade coffee is primarily a corporate strategy to increase profitability through creative marketing of products designed to appeal to the consciences of affluent consumers. Marketing techniques concerned with market segmentation and product differentiation are designed precisely to tackle issues of maintaining profitability in saturated markets. Niche products at the high-value end of the market may be identified through market research into consumer trends. Such research has, for example, highlighted trends towards ethical consumption, and the growing retail value of 'ethical brands' (see 'Ethical brands: the moral minority' Brand Republic, 3.08.05; 'Rise of the new premium "pukka consumer"', Brand Republic, 7.11.06, http://www.brandrepublic.com/). In its market research report on attitudes towards 'ethical foods', Mintel (2006) concluded that Fairtrade sales in Britain had experienced a 265\% growth since 2002 and that 25\% of all adults, and $32 \%$ of those in socio-economic category AB, aim to buy Fair Trade products where possible. Such reports indicate that an 'ethical image' may increase the profitability of a branded product. It is notable that each of the dominant coffee importers and roasters (Nestle, Kraft, Procter and Gamble and Sara Lee) have recently introduced new, high value, niche brands symbolising their commitment to equitable trade. Each has made changes in promotional and product strategies, either buying a small percentage of their green coffee through the international Fair Trade Labelling Organisation (FLO, 2005), or translating the fair trade concept into their own equity-based instruments for purchasing green coffee. Sara Lee uses the Prebica Whole Planet label for Fair Trade certified coffee. Nestle sells a FLO-certified 
Partners' Blend ( http://www.nestle.co.uk/

PressOffice/MediaKit/PressReleases/FoodandBeverageNews/PartnersBlendLaunch.htm). Kraft opted for certification of some of its purchasing through the US-based Rainforest Alliance http://www. rainforestalliance.org/, which prioritises environmental sustainability criteria, but does not guarantee a minimum price to coffee farmers. Procter and Gamble have added both Fair Trade-, and Rainforest Alliance-certified products to their niche market 'Millstone' brand, but have made no change to their major brand, Folgers.

4.2 Fair Trade products are however only one component of corporate strategies. At the low value end of the market, new niche instant, and flavoured, coffee products have also been devised by taking advantage of poor quality, low price Robusta beans now grown in countries such as Vietnam. Investment in processing technologies to exploit lower quality beans, combined with falling prices for green beans, financial tools to hedge against price fluctuations and just-in-time supply chain management, have enabled corporations to maintain profit margins of between $17 \%$ and $26 \%$ on ground and instant coffee respectively. The share of the retail value of coffee returned to original producer countries has however declined from around $30 \%$ to around $10 \%$ in the last decade (Gresser and Tickell, 2002; Lewin et al, 2004; Murray et al, 2003). In the consumer coffee market, new Fair Trade products may therefore simultaneously act as a means of enhancing profitability at the margins, and as a cosmetic device to disguise from ethically-oriented consumers the dominant strategy of cost-cutting, and intensive exploitation of lower quality coffee. Market segmentation thus delivers greater returns to large companies than to small farmers, while perhaps salving the consciences of the better off.

4.3 Interest in ethical consumption is clearly susceptible to forms of co-option by large corporations through innovative marketing and products. Indeed theorists of consumer culture such as Bauman (2000; 2004) contend that resistance to certain products, and active buying of alternatives, serves mainly to fuel further cycles of consumerism and to reinforce the power of the large corporations. Taking this perspective to its logical conclusion however entails the acceptance of a determinist view of socio-economic relations, which is not confirmed by the history of social change. Evidence of ethical attitudes to consumption, and changes in buying habits, cannot be explained without reference to a social movement stimulating change. In relation to the particular example of coffee, it is difficult to explain why major corporations, which dominate a coffee market with an estimated annual retail value of $\$ 55$ billion, and maintain high profit margins, would bother to invest in Fair Trade products at all, unless new market actors were perceived to threaten their reputation, and to present a significant challenge to the dominant, cost-cutting, trade paradigm.

\section{Explaining the Rise of Fair Trade Coffee 2: the Role of NGOs and Alternative Trade Networks?}

5.1 That challenge, it is argued here, is a result of the, perhaps counter-intuitive, influence of a globally dispersed, loosely networked, and continuously evolving consumer movement, rooted in Non-Governmental Organisations (NGOs) and their associated alternative trade networks. The rapid growth in sales of Fair Trade coffee has led market analysts to suggest that it is erroneous to define such products simply as a phenomenon of 'niche marketing'; instead, Lewin et al (2004) suggest, they represent the emergence of a new trade paradigm where social, environmental and ethical concerns 'will continue to emerge as...basic rules of the game and prerequisites for participation' (p.14). In other words, it is inadequate to dismiss Fair Trade coffee as nothing more than a new marketing ploy for exploiting consumer guilt in the interest of corporate profitability. *

\section{The Origins of Fair Trade Coffee Campaigns}

5.2 Current Fair Trade coffee campaigns were triggered predominantly by the collapse, in 1989, of the regulatory framework for green coffee prices. For around fifteen years prior to 1989 , the International Coffee Agreement governed target prices (latterly between $\$ 1.20$ and $\$ 1.40$ per lb) and export quotas. Tensions between members, and the eventual withdrawal of the USA on the grounds that the system was inflexible and allowed non-members to undercut target prices, resulted in the end of the Agreement (Bates, 1998). The removal of export quotas provided incentives for poorer countries to expand coffee growing as a means to generate foreign exchange and finance debt. The result has been a global surplus and a sharp decline in green coffee prices to a 100-year low (ICO, 2006): between 2004 and 2007 the International Coffee Organisation (ICO) indicator composite price has varied from $\$ 0.62$ to $\$ 1.06$ per lb (www.ico.org/coffee_prices.asp). The radical decline in prices has had devastating social consequences for the twenty to twenty-five million coffee-farming families in developing countries who are dependent on the income generated from selling their harvest ${ }^{[2]}$ (Bates, 1998; Paige, 1998; Lewin et al, 2004). The consequences for economic and political stability of the main exporting countries in Latin America, Africa and Asia, have been reported and debated by international governance bodies including the United Nations, World Bank and IMF. 
as 'consumers' in affluent societies, who shaped the development of a consumer movement with alternative products designed to embody a critique of the imbalance of power in the commodity market and of the growing poverty of coffee farmers. The movement for Fair Trade coffee is not an isolated phenomenon, but part of the wider human rights, anti-poverty, environmental and trade justice movements, which have marked the last forty years in Western democracies (Della Porta and Diani, 2006; Inglehart, 1997; Poletta and Jasper, 2001). In relation to coffee, the initial impetus for alternative trade relied on a core of activist organisations which were instrumental in developing an infrastructure for trust-based supply chain relations with small farmers, and for experimentation with labelling as a means to distinguish, and impute meaning to, an alternative product. These organisations in turn bear marks of their history from at least the 1950s, when alternative trading organisations, such as Oxfam World Shops or 'goodwill selling' in the USA, initiated the sale of craft products imported from rural Asia, Latin America and Africa. Such projects used alternative trade simultaneously as a device for public awareness-raising, and as a means of establishing pre-figurative forms for trade relations based on principles of long-term cooperation and trust rather than adversarial shortterm price competition (James, 2002). During the late 1980s, when the International Coffee Agreement was faltering, NGOs working with small coffee farmers sought to adapt these principles to coffee. 'Equal Exchange', based in Boston (USA), for example began importing and selling Nicaraguan coffee in support of the Sandinista movement. Dutch religious organisation Solidaridad, working in Mexico, took a further step when they conceived the idea of a Fair Trade label as a device to distinguish products bought and sold under fair trade conditions. The Max Havelaar ${ }^{[3]}$ label was established to market Mexican and Nicaraguan coffee, which gained a $3 \%$ market share in the Netherlands. *

\section{Developing an alternative supply chain}

5.4 Most green coffee is traded as a bulk commodity on the New York and London global coffee exchanges, in a highly rationalised supply chain reliant on financial tools to manage just in time supply while hedging against price fluctuations. Since the late 1980s, organisations campaigning for fair trade have sought to intervene in markets through alternative supply chain development, marketing and product innovations:

'The spread of fair trade practices is facilitated by the existence of extended networks of cooperatives and small retail operators in the West, who try somehow to reach a balance between ethic-driven public action and market requirements' (Della Porta and Diani, 2006: 4).

5.5 The activist core of organisations have established increasingly co-ordinated networks, to govern quality standards, environmental and social criteria, and minimum prices, as is evident in the infrastructure of the European Fair Trade Association (EFTA) ${ }^{[4]}$ http://www.european-fair- trade-association.org/, the Fair Trade Federation (USA) http://www. fairtradefederation.org/ and the UK-based International Federation for Alternative Trade (IFAT) http://www.ifat.org/. The federations act as forums for exchange between producer associations and alternative importers, marketing organisations and retailers and create a web of connections to European, North American and Pacific Rim 'ethical consumers'. IFAT for example has a network of approximately 300 organisations in around 60 countries in Asia, Africa, Latin America, Europe, North America, and the Pacific Rim. Research has demonstrated the problems and limitations of such arrangements in involving and empowering coffee farmers (Lyon, 2006), but nevertheless the transformative potential of an alternative Fair Trade infrastructure is evident in the growth of Fair Trade coffee sales. *

\section{Alternative Trade Organisations 'Re-qualify' Coffee}

5.6 The 'problem' of distinguishing fairly traded coffee from established, branded products, and of destabilising the meanings and qualities attributed to the latter, has been addressed by the development of a Fair Trade label or 'brand'. The creation of an international Fair Trade Labelling Organisation (FLO) (http://www.fairtrade.net/) in 1997, represents the most recent attempt to unify labelling and certification processes. The FLO is an alliance of 20 nationally-based alternative trade federations, spanning North America, Australasia and Europe. For coffee, it charges members a 2\% Fair Trade certification fee, based on wholesale coffee prices, and coordinates the auditing and monitoring of production and trade standards, and labelling of products ${ }^{[5]}$. The FLO annual report (2005) concludes that sales of labelled products account for the most significant part of the increase in the estimated global retail value of fair trade goods to 1.1 billion Euros, an increase of $37 \%$ over the previous year. In Europe, Krier (2005) estimates that $91 \%$ of the wholesale value of all fair trade products was in Fair Trade labelled goods, with coffee accounting for approximately one third of this (Fair Trade Federation, 2005).

5.7 CafeDirect http://www.cafedirect.co.uk/ in the UK also serves as a prominent example of the impact of labelling on retail sales. Founded in 1990, as a joint venture between Oxfam, Traidcraft, Equal Exchange and Twin Trading, it imports, roasts and packages coffee from 33 producer organisations. It returns $86 \%$ of its operating profits to producers' business development projects. Between 2000 and 2005, its annual 
growth averaged $20 \%$, with turnover increasing from 12 million Euros to 25.2 million. Having launched the first of the UK Fair Trade labelled coffee products, it has gained an increasing share of the market in roast and ground coffee in particular, becoming the fourth largest of the established brands.

5.8 Fair Trade labelling has provided a symbol of standards relating to material qualities of coffee flavour, but has above all implicated the social relations of production and consumption in the qualities of the product. It builds the symbolism of a critique of commodity chain relationships between growers, producers, retailers and consumers into the materialism of the pack of coffee, with the 'fair trade' product imputing a connection between the lives of low-income farmers and those of affluent consumers (Raynolds, 2002). Introducing the idea of the qualification of products draws attention to the social processes which define a product as a 'good'. The qualities attributed to products, and their status as 'goods' or 'bads', are not inherent in the artefacts, but are subject to negotiation, and struggle, between market actors, who may include economists, producers, consumer groups, scientists and international governance bodies (Callon et al, 2002). As a device, labelling has provided the organised fair trade networks with a means of contesting, destabilising and revising the positive qualities conventionally attributed to established brands. Such labelling also signals a change in the politics of resistance by demonstrating the possibility of alternative trade relations among corporate actors, non-governmental organisations and governments. *

\section{A Developing Collective Identity and Infrastructure for Fair Trade: core activist organisations mobilise wider networks by framing the issues and identifying shared purposes}

5.9 Growth in sales depends critically on public awareness and understanding of fair trade products and of the rationale for buying them. The concept of 'globalisation from below' has been used to characterise the emergence of alliances between diverse social movement groups and organisations, articulating connections between issues such as fair trade, human rights, ecology and well-being, and crafting common cause (Della Porta et al, 2006; Falk, 1993). Broadly-based public protest movements, such as the Make Poverty History campaign (http://www.makepovertyhistory.org/), and global coalitions of organisations such as Consumers International (http://www.consumersinternational.org/) have debated the links between poverty and the contemporary forms of global trade, and argued for trade justice and sustainable consumption and production.

5.10 In the case of coffee, alliances between civil, political and religious groups have provided a means to develop wider public awareness of the poverty experienced by coffee growers, and to appeal to cultural values of self-sufficiency and self-respect for producers, using catch phrases such as 'trade not aid'. The UK Fairtrade Foundation (http://www.fairtrade.org.uk/), established as a charity in 1992 by CAFOD, Christian Aid, New Consumer, Oxfam, Traidcraft and the World Development Movement, and latterly the Women's Institute, has for example worked to deepen understanding of fair trade, through developing its practices and criteria, and licensing the use of the Fair Trade mark. The rationale for fairness and justice in relations between producers and consumers has been articulated through Fair Trade events, conferences, videos, reports and press releases, supported by a growing internet presence. Alternative products and promotional devices, designed to reveal the original producers to consumers of processed coffee, have been used to demonstrate the feasibility of fair trade and to appeal to socially organised, collective expressions of material/economic consumer power. The movement has become widely dispersed, with Local Authorities supporting fair trade principles, and making commitments to consume fair trade tea and coffee: $218 \mathrm{UK}$ towns and cities are designated as Fair Trade places and a further 254 are listed as working towards such status (http://www.fairtrade.org.uk/get_involved_fairtrade_towns.htm). Fair trade coffee is also sold in the UK House of Commons, the Scottish Parliament, the National Assembly of Wales, the DTI and the DfID. Mainstream retailers, notably café chains such as those in Marks and Spencer plc stores, have also become keen to demonstrate their ethical credentials by selling Fair Trade coffee.

5.11 Alliances among social movement organisations, and their growing embeddedness within civil society, have thus been instrumental in influencing cultural values and in creating an infrastructure and alternative market for coffee products: these 'acephalous, horizontal, loosely networked alliances... have emerged as major actors' (Edelman, 2001: 305). *

\section{The 'outer edge' of the movement: quasi-organised consumers}

5.12 Evidence of a shift in cultural values commensurate with the notion that consumption activities are susceptible to ethical considerations, and may be shaped by a sense of connection to a loosely defined social movement, is provided by Majima and Savage's (2006) analysis of UK data from the World Values Survey between 1981 and 1999. They conclude that the values of a professional and educated middle class, as well as those of young people, have become more rebellious and conscientious, and less individualistic and libertarian. Rather than passivity in the face of the seductions of mainstream marketing and advertising, there is evidence that the monetary logic of the market and individualised consumption 
5.13 Such activities, engaged in by loosely-defined social movements, or even uncoordinated, anonymous crowds, are not the result of centralised strategies defined by structured organisations with formal membership. A social movement identity can be adopted by people who are 'detached from every organisational allegiance' (Della Porta and Diani, 2006: 99). Fair Trade sales have grown not only because of commitment generated by direct participation in mass protest campaigns such as Jubilee 2000 or Make Poverty History, but also through uncoordinated, or only extremely informally and tangentially coordinated, banal actions such as those entailed in deciding between one brand of coffee and another. Initiatives such as Fair Trade Labelling have enabled, 'quasi-organised consumers', acting as part of a largely imagined group of like-minded, but unknown, others, to use economic capital to express cultural common cause. What Granovetter (1985) identified as the 'strength of weak ties' serves as a reminder of the connections between any given person and a member of a voluntary group, charity, local council, trade union or religious organisation, and in turn to social movements concerned with fair trade.

5.14 In an era where communication is heavily internet-mediated, direct personal knowledge of, or interaction with, members of Fair Trade organisations, is not a prerequisite for participation. The widely dispersed virtual networks of on-line communities, with identifiable products, can be used to indicate a political attitude, such that 'knowing someone who knows someone' is not critical in order to participate. The multi-faceted Fair Trade movement exists, not only as a material one through its activist organisations and products, but also as a virtual and boundary-less one through its internet presence, which potentially draws in anyone with access to networked computing.

5.15 Participation can be as limited as deciding on a single occasion to use economic capital to express cultural common cause: 'political consumers act individually or organize collectively in coordinated or spontaneous actions. Their concern with the "politics of products" - environmental effects, shared costs for workers and consumers, and human rights impacts - reflects an understanding of material products as embedded in a complex political, social, and normative context' (Micheletti 2004: 4). Such participants are using cultural and economic resources to question rationalised markets and exploitative trade relations.

\section{Explaining the Rise of Fair Trade Coffee 3: Organised Consumers?}

6.1 Saturated markets, dominated by trans-national firms operating in a rationalised commodity chain, seem to be unpromising terrain for consumer activism. While the impact of campaigns should not be overstated, rapid growth in the retail market for Fair Trade coffee is a significant example of the performative role of organised consumer movements as market intermediaries. Prior to 1989 'a coalition among bureaucrats, politicians and firms' (Bates, 1998: 216) used the power of states to restructure markets through the International Coffee Agreement. The movement for fairly traded coffee relies instead on a coalition among disparate and fluid civil groups to use the cultural and material resources of consumers to reshape the balance of power, by disrupting the symbolic meanings and status of established coffee brands, and 're-qualifying' coffee products. The transformation of consumerism into a specific target of collective action (Della Porta and Diani, 2006; Norris, 2002; Wahlstrom and Peterson, 2006) demonstrates that consumption practices are not informed simply by considerations of personal needs and ephemeral desires (Bauman, 2000; 2004; Elliott and Lemert, 2006), but are also subject to political and ethical considerations, and scepticism towards the values and products of consumerism.

6.2 The 'organised consumers' who are reshaping coffee markets are not a single or fixed entity, but are comprised of a multi-layered and continuously changing social movement whose networks are critical of exploitative supply chains, and of governments' and global corporations' part in these. Moving beyond criticism, an activist 'core' have established an alternative supply chain in coffee. Since the 1980s this has developed into extensive alternative trade networks, which span the globe and represent organisations as varied as large charities such as Oxfam, to single outlet retailers linked through Fair Trade federations. Activists are not 'the isolated, atomistic individuals sociologists once took them for' (Poletta and Jasper, 2001: 289), but have been instrumental in articulating the connections between the fair trade coffee project and the wider goals of social movements concerned with participative democracy, social justice, equality, environment, pacifism and so on. The gradual institutionalising of the fair trade concept, represented in the establishment of the international Fair Trade Labelling Organisation, has facilitated the collaboration of a shifting coalition of disparate and fluid social movement organisations, civil and religious groups, who have furthered the principals of fair trade at local levels. Their mobilisation is facilitated by fluid association between multiple centres and dispersed groups of sympathisers, and by the ease of internet communication which reduces costs, and enhances trans-issue and transverse interaction across the globe (Della Porta et al, 2006). At its most dispersed, the agency of organised consumers is demonstrated in rising sales of Fair Trade coffee, reflecting the consumption choices of people acting largely as members of an imagined collectivity, who may shift allegiance over time, experiment with alternatives to the established brands and engage further in other actions, or not. 
6.3 Sociology has struggled to give a coherent account of such social movements and to explain why they might arise in particular circumstances (Appadurai, 2000; Edelman, 2001): 'scholars have come late to the party' (Keck and Sikkink, 1998: 4). Their stimulus has generally been located in an account of the rise of advanced capitalist societies. Industrialisation, secularisation, democratisation and their associated individualised life course trajectories constitute identity as something to be achieved, rather than as a matter of birth, and as marked by a degree of voluntarism (Giddens, 1991; Kumar, 1988). In the 1980s European theories characterised New Social Movements (NSMs) as emerging out of the resulting 'crisis of modernity' and existential search focused on the symbolic and cultural resources of personal and social identity (Touraine, 1988; Melucci, 1989; Edelman, 2001). Unlike trade union and labour movements, NSMs were viewed as a critique of modern ideas of progress through individualisation, representative democracy and anonymous bureaucracy, and as a defence of participative organisation forms, mutual dependence and social solidarity. Theorists have latterly acknowledged that claims about the 'newness' of such movements reflected mistaken assertions about their historical uniqueness and the supposed novelty of the processes in question (Della Porta and Diani, 2006). Nevertheless this does not remove the need to understand the relationships between social change in different historical periods and forms of organised resistance or activism. Hence the processes of organised consumerism can at least conjecturally be located in the socio-structural conditions of advanced capitalism, without necessarily claiming that analogous processes and practices have never previously existed ${ }^{[6]}$.

6.4 Theories of change in such societies suggest that neo-liberal political economy and deregulated capital markets have resulted in growing disconnection between civil society and a global/cosmopolitan power elite (Castells, 2000; Froud et al, 2006). While significant proportions of the population of such societies are likely to be members of civil organisations, from churches to voluntary groups to political parties or trade unions, such organisations, Castells (2000) suggests, have declining access to institutionalised power. Yet these are societies which attribute individual autonomy and responsible citizenship to their populations (Melucci, 1989). The experienced voluntarism of identity, combined with a sense of personal responsibility for actions, and the experience of being marginalised from power, seem likely to provide favourable terrain for social movements which pursue alternative means of political influence. Such movements are marginal to the material bases of power, but their members are also distant from ideological control of those in power (Hirsch, 1990), and may deliberately distance themselves from such control.

6.5 Theories of social movements have typically emphasised either the expressive and emotional aspects of movement identity, or their rational and reasoned bases (Della Porter and Diani, 2006). The 'core activist' organisations of the fair trade movement are not directly concerned with personal existential search, any more than they directly embody class conflicts between capital and labour, or 'interest group' politics. Instead they combine the 'expressive and the rational-instrumental' by seeking to mobilise the cultural and economic capital of the relatively affluent in the interest of improving the livelihoods of unknown others, through alternatives to the inequalities of global divisions of labour and trade. In societies where state and market rationalise the private sphere (Klein, 2000; Melucci, 1989), social movement organisations provide a cultural space to develop 'counter-hegemonic ideas and oppositional identities (Poletta and Jasper, 2001: 288). Such spaces enable participants to develop alternative values to those of the market, to contest dominant conceptions of an instrumental consumer identity, and to consider the connections between cultural values and economic action. Beliefs and values embodied in such self-organising movements entail normative and moral ties of loyalty and obligation to act, and are likely to represent a meaningful form of autonomy and personal responsibility for participants. Presenting consumption as a matter of ethical choice means that it can be made to represent a political act of taking responsibility for the products available through consumer markets, and practicing particular values (Della Porta and Diani, 2006).

6.6 In order to perceive the agency of organised consumers it is therefore necessary to look outside a frame of reference which assumes a consumer identity manifested in individualised self-interest at the point of monetary exchange. Forms of collective consumer identity and agency are evident in social movement organisations, religious groups, charities, trade unions, local civil society and so on. In modern capitalist societies, people are likely to perceive themselves as having multiple identities, which are not necessarily commensurable: 'identifying with a movement does not necessarily mean sharing a systematic and coherent vision of the world' (Della Porta and Diani, 2006: 98). Those positioned as consumers in advanced capitalism look to other sources of collective social identity, derived from a public domain, to influence markets through cultural articulation of an alternative ethical stance expressed in material forms of economic action.

\section{Re-interpreting Consumption and Markets: the Wider Implications}

7.1 The 'methodological individualism' (Warde, 2005) of sociological accounts of consumerism has lost sight of the diversity and complexity of consumption practices, and of the mediating influence and agency 
of organised consumers. Generalising theories of consumerism offer persuasive accounts of the workings of power through forms of subjectivity, culture and values, but they neglect the capacity of people to evaluate their situation and to make changes in it. The deterministic argument that identity is captured by consumerism can be rejected on the grounds that it misunderstands the connections between macro-level political-economy and micro-level activities: nothing dictates how we act, 'although there are plenty of forces inducing us this way or that' (Archer, 2000: 319). Scepticism towards producers' claims does not of course guarantee immunity from the seductive power of consumerism. Many of the forces framing social interaction arise out of the network of market institutions, and its predominant values of materialism and individualism, providing the circumstances for action. Nevertheless the inventive power of marketing is not passively received, and people's experience of the contradictions between the promises of consumerism and the demands of work and life, contribute to a continuing critical awareness of political-economy and consumer culture. The qualities invested in products by corporate marketing and advertising may be creatively consumed, or resisted and challenged. The consumer movement for fairly traded coffee illustrates the innovative qualities of agency, expressed in this case through the construction of pre-figurative forms for alternative producer-consumer relations, and the adaptation of rationalised tools of branding and labelling. Introducing the organisational level of analysis, in relation to the shaping of consumer identities, provides insight into the intensive social mediation of 'consumer choice' and its continual re-interpretation, by nonexpert as well as expert groups. Organised, non-expert market actors, who scrutinise market products and construct alternatives, are neglected both by cultural theorists such as Bauman and by economic sociologists such as Callon.

7.2 Consumer agency is demonstrated not just in patterns of spending, but also when those positioned as consumers look to other sources of social identity to shape markets. The attributed identity of 'sovereign consumer' in affluent societies is itself contested terrain, politicised through consumer movements which give voice to ambivalent attitudes to mass market goods, question the trustworthiness of large firms, and make demands on governments and corporations to change the terms of trade. The result is a dialectical relationship between rationalised production and consumption arrangements, and the improvisatory, flexible and creative tactics deployed by those variously positioned as consumers (De Certeau, 1984).

7.3 While the forms of agency exercised by organised consumers are at the margins of mass consumer markets, they are nevertheless powerful in confronting the contradictions and irrationalities of contemporary consumerism.

7.4 The case of fair trade coffee demonstrates that such actors contribute to the constitution of consumer markets, in indeterminate interaction with commodity traders, producers, retailers, and public bodies. Rising sales of Fair Trade coffee demonstrate the on-going negotiability, and malleability, of product qualities. In the context of consumer criticism of industrialised food production, the trade networks of Fair Trade, organic, shade grown or single origin coffee have acted to distinguish alternative product qualities through processes of standardisation and certification designed to symbolise social solidarity as well as flavour, ecology or regional identity (Renard, 1999). Organised consumers, acting as market intermediaries, have contested, and destabilised the qualities of established brands of coffee, and revised both the material and the symbolic qualities of products. Fair Trade labelling has shaped and responded to changing consumer consciousness of the qualities of products and their relative status as 'goods' and 'bads'. At present, this has had limited impact on lower-priced flavoured and instant coffee products, but it is evidence of the performative role of organised consumers in the directions of markets. It is also testament to the social complexities of markets, the multiplicity of market actors and the inevitable indeterminacy of market directions.

7.5 The concept of 'organised consumers' is a lever to open up to investigation the remaking of markets through the devices of non-expert collective actors, who scrutinise the claims and practices of large-scale producers. It offers a link between generalising macro-level theories of political economy and supply chains, and individualising, micro-level accounts of consumption and identity. Explaining the emergence of such informally-organised actors, and predicting their future trajectories, is difficult. Analyses of social movements and their organisations have concluded that they are not unique to the current period, but the particular characteristics of consumer activism and its ethical stance still needs to be accounted for. In their analysis of markets in advanced capitalism, Callon et al (2002) interpret consumers' preferences as located in dynamic cultural and political-economic processes, which situate products in comparative relationships to each other. They argue that there is an emerging 'economy of qualities', where new forms of scientific and technical expertise, and hybrid material/cultural technologies, are making the negotiability of markets and product qualities more evident and revealing once again the political character of markets.

7.6 Emphasising the role of technical innovation however understates the impact of the drive by governments to expand the sphere of the market in public and private life as a stimulus to organised and politicised consumers (Blythman, 2004;Cohen, 2003; Klein 2000; Lawrence, 2004). By the same token, 
deregulated global capital markets, which have made capital more mobile, have emphasised share price as the key indicator of corporate performance (Froud et al, 2006). Businesses have consequently become more sensitive to the effects of adverse publicity, emanating from consumer boycotts and 'buycotts', on corporate brands and share values. Such 'reputational risk' is seen as having a material impact on profitability, resulting in corporations investing considerable resources in defending their products and strategies against public criticism (Gioia et al, 2004; Hatch and Schultz, 2004). This suggests that the activism of organised consumers is not simply the result of new forms of product innovation in an emerging economy of qualities, but is integral to the dialectical relationships between producers and consumers in the political opportunity structures of a neo-liberal economic regime.

7.7 The significance of changes in business strategy in relation to mainstream coffee products, and the future of the Fair Trade movement in general, is much debated. It would be erroneous to imply that, because an alternative form of trade is established in one part of the market, it will inevitably spread throughout all consumer product markets. In discussions about the growth of Fair Trade sales, defenders of free market ideals present Fair Trade coffee as distorting the market, resulting in overproduction. Corporate strategies, it is suggested, are driven solely by consumer demand, and there is limited demand for 'causerelated' coffees (Lindsey, 2004). Conversely proponents of fair trade have argued that oligopoly allows the corporations to mould the market to their own ends of continually increasing profitability, while ignoring the social and environmental costs of their practices (Gresser and Tickell, 2002). In these terms, the rising sales of Fair Trade coffee are not the result of market distortion, but evidence of a free market working to enable more affluent consumers to choose a product which guarantees some benefits for producers, thus matching demand in a way that ensures future supply (Baggini, 2007).

7.8 Responses by large scale producers to the 'reputational risk' of Fair Trade show the adaptability of a global capitalism dominated by trans-national corporations to dissenting groups. This does not negate the fact that markets are the creation of multiple actors, including organised consumers, whose activities have been instrumental in an emerging new trade paradigm which is not owned by dominant end-producers. Organised consumers have moved beyond concern with the quality and price of products to investigate conditions of production, rates of profit and the terms of trade itself. The vitality of such consumer movements challenges economistic, market definitions of self interested individualism, pitting this projected identity against a common interest in social solidarity.

\section{Acknowledgements}

Thank you to anonymous reviewers for help in developing the paper, and to the Edinburgh Sociology Seminar audience for their interest and encouragement. A particular thank you to Hugo Gorringe and Jonathan Hearn for their insights, and to David McCrone for his knowledge of the sociology of social movements.

\section{Notes}

1 Transfair is the North American branch of the Fair Trade Labelling Organisation which certifies and regulates products.

${ }^{2}$ Approximately $70 \%$ of coffee is grown on farms of less than 25 acres, the majority being less than half this size (Gresser and Tickell, 2002).

${ }^{3}$ Max Havelaar is the title of an 1860 novel which criticised Dutch colonial policy in the East Indies, and the exploitation of Indonesian coffee workers. It is regarded as contributing to early awareness of the poverty and starvation caused by colonial policies.

${ }^{4}$ EFTA was established in 1987, forming an association of the 11 largest importing organisations in nine European countries.

${ }^{5}$ Importers agree to independent monitoring, and pay a minimum price to producer cooperatives. The price for coffee in 2007 is $\$ 1.26$ per lb, including a social premium to be invested in community development. If the price on the international exchanges rises above the minimum, farmers receive the market price plus a $\$ 0.05$ per lb social premium. Buyers are also required to provide producers with credit at fair terms to enable them to avoid debt to local intermediaries, and are expected to establish long term trading relationships with producer cooperatives.

${ }^{6}$ Similar processes are evident in the anti-slave trade movement where moral convictions over-rode 
individualistic concerns about means-ends rationality and posed a challenge to dominant modes of production. Writing on the abolitionist movement highlights the fact that the moral/cultural argument had to be won before it had real effects. Only after slavery had successfully been recast as morally flawed did the movement gain ground (Personal communication, Hugo Gorringe, 2006).

\section{References}

APPADURAI, A. (2000) 'Grassroots globalization and the research imagination', Public Culture, 12 (1): 119.

ARCHER, M. (2000) Being Human: the Problem of Agency . Cambridge: Cambridge University Press.

BAGGINI, J. (2007) 'Free doesn't mean unfair' Guardian Monday March $5^{\text {th }}$, p.29 http://environment.guardian.co.uk/food/story/0,,2026547,00.html

BATES, R. (1998) 'The International Coffee Organization: an International Institution' in Bates, R., Grief, A., Levi, M., Rosenthal, J-L. and Weingast, B. (eds) Analytic Narratives. Princeton NJ: Princeton University Press.

BAUMAN, Z. (2000) Liquid modernity. Cambridge: Polity Press.

BAUMAN, Z. (2004) 'The consumerist syndrome in contemporary society', Journal of Consumer Culture, 4: $291-312$.

BLYTHMAN, J. (2004) Shopped: the Shocking Power of British Supermarkets . London: Fourth Estate.

BOSTRUM, M., Føllesdal, A., Klintman, M., Micheletti, M. and Sørensen, M. (2004) 'Studying political consumerism' in Political Consumerism: Its Motivations, Power, and Conditions in the Nordic Countries and Elsewhere. Proceedings from the 2nd International Seminar on Political Consumerism, Oslo August 26-29, 2004, Copenhagen: Norden.

CALLON, M. (ed) (1998) The Laws of the Markets, Oxford: Blackwell.

CALLON, M., Meadel, C. and Rabeharisoa, V. (2002) 'The economy of qualities', Economy and Society, 31: 194-217.

CASTELLS, M. (2000) The Rise of the Network Society, Oxford: Blackwell. $2^{\text {nd }}$ Edition.

COHEN, L. (2003) A Consumers' Republic: the Politics of Mass Consumption in Post-war America . New York: Alfred A. Knopf.

DE CERTEAU, M. (1984) The Practice of Everyday Life . London: University of California Press.

DELLA PORTA, D. and Diani, M. (2006) Social Movements: an Introduction, Oxford: Blackwell. $2^{\text {nd }}$ Edition.

DELLA PORTA, D., Andretta, A., Mosca, L. and Reiter, H. (2006) Globalization from Below: Transnational Activists and Protest Networks, Minneapolis: University of Minnesota Press.

EDELMAN, M. (2001) 'Social movements: changing paradigms and forms of politics', Annual Review of Anthropology, 30: 285-317.

ELLIOTT, A. and Lemert, C. (2006) The New Individualism: The Emotional Costs of Globalization , London: Routledge.

FAIR TRADE LABELLING ORGANISATION INTERNATIONAL (FLO) (2005) Annual Report: Building Trust www. fairtrade.net

FAIR TRADE FEDERATION (2005) Fair Trade Trends in North America and the Pacific Rim, Washington, DC, USA www. fairtradefederation.org

FALK, R. (1993) 'The making of global citizenship' in J. Childs, J. Brecher and J. Cutler (eds) Global Visions: Beyond the New World Order, Boston: South End.

FROUD, J., Johal, S., Leaver, A. and Williams, K. (2006) Financialization and Strategy, Narrative and Numbers, London: Routledge. 
GIDDENS, A. (1991) Modernity and Self Identity . Cambridge: Polity Press.

GIOIA, D., Schultz, M. and Corley, K. (2004) 'Organizational identity, image and adaptive instability', in M. Hatch and M. Schultz (eds) Organizational Identity: a Reader. Oxford: Oxford University Press.

GRANOVETTER, M. (1985) 'Economic action and social structure: the problem of embeddedness', American Journal of Sociology, 91 : 481-510.

GRESSER, C. and Tickell, S. (2002) Mugged: Poverty in Your Cup, Oxfam International, www.maketradefair.com.

HATCH, M. and Schultz, M. (2004) 'The dynamics of organizational identity' in M. Hatch and M. Schultz (eds) Organizational Identity: a Reader. Oxford: Oxford University Press.

HIRSCH, E. (1990) 'Sacrifice for the cause: group processes, recruitment and commitment in a student social movement', American Sociological Review, 55: 243-54.

HOLZER, B. (2006) 'Political consumerism between individual choice and collective action: social movements, role mobilization and signaling' International Journal of Consumer Studies , 30: 405-415.

ICO Coffee Market Report, 2006 http://dev.ico.org/index.asp

INGLEHART, R. (1997) Modernization and Postmodernization: Cultural, Economic and Political Change in 43 Societies. Princeton: Princeton University Press.

JAMES, D. (2002) 'Consumer activism and corporate accountability: A history of the fair trade movement' Journal of Research for Consumers , Issue 3, September. http://www.jrconsumers.com/

KECK, M. and Sikkink, K. (1998) Activists Beyond Borders: Advocacy Networks in International Politics . Ithaca, NY: Cornell University Press.

KLEIN, N. (2000) No Logo. London: Harper Collins/Flamingo.

KRIER, J-K (2005) Fair Trade in Europe: Facts and Figures on Fair Trade in 25 European Countries . Brussels: Fair Trade Advocacy Office (FLO, IFAT, EFTA, NEWS) and Heinrich Boll Foundation.

KUMAR, K. (1988) The Rise of Modern Society. Oxford: Blackwell.

LAWRENCE, F. (2004) Not on the Label. Harmondsworth: Penguin.

LEWIN, B. Giovannucci, D. and Varangis, P. (2004) Coffee Markets: New Paradigms in Global Supply and Demand. Washington, DC, USA: World Bank Agriculture and Rural Development Department.

http://Inweb18.worldbank.org/ ESSD/ardext.nsf/11ByDocName/

CoffeeMarketsNewParadigmsinGlobalSupplyandDemand/\$FILE/ CoffeeMarkets-ArdDp3.pdf

LINDSEY, B. (2004) Grounds for Complaint? 'Fair Trade' and the Coffee Crisis. London: Adam Smith Institute, www.adamsmith.org

LYON, S (2006) 'Evaluating fair trade consumption: politics, defetishization and producer participation', International Journal of Consumer Studies , 30: 452-464.

MAJIMA, S. and Savage, M. (2006) Unpacking Culture Shifts In Post-War Britain: A Critical Encounter With Ronald Inglehart. CRESC Working Paper 17, University of Manchester. www.cresc.ac.uk

MALLARD, A. (2006) 'Evaluating telecommunications products and services: consumerist tests as economic experiments', France Telecom Research \& Development Laboratory Sociology of Uses and Statistical handling of Information, Issy les Moulineaux.

MELUCCI, A. (1989) Nomads of the Present. London: Hutchinson.

MICHELETTI, M. (2003) Political Virtue and Shopping: Individuals, Consumerism and Collective Action . Basingstoke: Palgrave Macmillan.

MICHELETTI, M. (2004) Just Clothes? Discursive Political Consumerism and Political Participation, ECPR Joint Sessions, April 13-18, Uppsala, Workshop 24: Emerging Repertoires of Political Action. Toward a Systematic Study of Postcoventional Forms of Participation.

MINTEL (2006) Food Retailing - UK - November 2006 . London: Mintel International Group Ltd. 
MURRAY, D., Raynolds, L. and Taylor, P. (2003) One Cup At A Time: Poverty Alleviation And Fair Trade Coffee In Latin America, Colorado State University Fair Trade Research Group http://www.colostate.edu/Depts/Sociology/FairTradeResearchGroup

PAIGE, J. (1998) Coffee and Power: revolution and the rise of democracy in Central America Cambridge, Mass.; London: Harvard University Press.

POLETTA, F. and Jasper, J. (2001) 'Collective identity and social movements', Annual Review of Sociology , 27: 283-305.

RAYNOLDS, L. (2002) 'Consumer/producer links in fair trade coffee networks', Sociologia Ruralis, 42: 404424.

RENARD, M-C. (1999) 'The interstices of globalization: the example of fair coffee', Sociologia Ruralis, 39: 484-500.

SMELSER, N. and Swedberg, R. (2005) 'Introducing economic sociology', in N. Smelser and R. Swedberg (eds) The Handbook of Economic Sociology. Princeton: Princeton University Press and Russell Sage Foundation.

STOLLE, D., Hooghe, M. and Micheletti, M. (2005) 'Politics in the supermarket: political consumerism as a form of political participation', International Political Science Review , 26: 245-269.

TOURAINE, A. (1988) Return of the Actor: Social Theory in Post-Industrial Society . Tranls. M. Godzich. Minneapolis: University of Minneapolis Press.

WAHLSTROM, M. and Peterson, A. (2006) 'Between the state and the market', Acta Sociologica, 49: 363377.

WARDE, A. (2005) 'Consumption and theories of practice', Journal of Consumer Culture, 5: 131-153. 